University of Nebraska - Lincoln

DigitalCommons@University of Nebraska - Lincoln

\title{
Molecular and morphophysiological responses cocoa leaves with different concentrations of anthocyanin to variations in light levels
}

\author{
Romária Pereira de Araújo \\ Instituto Federal Baiano, romaria.araujo@si.ifbaiano.edu.br \\ Alex-Alan Furtado de Almeida \\ State University of Santa Cruz, alexalan.uesc@gmail.com \\ Joedson Pinto Barroso \\ State University of Santa Cruz \\ Rosilene Aparecida de Oliveira \\ State University of Santa Cruz \\ Fábio Pinto Gomes \\ State University of Santa Cruz \\ See next page for additional authors
}

Follow this and additional works at: https://digitalcommons.unl.edu/usdaarsfacpub

Pereira de Araújo, Romária; Furtado de Almeida, Alex-Alan; Pinto Barroso, Joedson; Aparecida de Oliveira, Rosilene; Pinto Gomes, Fábio; Ahnert, Dário; and Baligar, Virupax C., "Molecular and morphophysiological responses cocoa leaves with different concentrations of anthocyanin to variations in light levels" (2017). Publications from USDA-ARS / UNL Faculty. 1775.

https://digitalcommons.unl.edu/usdaarsfacpub/1775

This Article is brought to you for free and open access by the U.S. Department of Agriculture: Agricultural Research Service, Lincoln, Nebraska at DigitalCommons@University of Nebraska - Lincoln. It has been accepted for inclusion in Publications from USDA-ARS / UNL Faculty by an authorized administrator of DigitalCommons@University of Nebraska - Lincoln. 


\section{Authors}

Romária Pereira de Araújo, Alex-Alan Furtado de Almeida, Joedson Pinto Barroso, Rosilene Aparecida de Oliveira, Fábio Pinto Gomes, Dário Ahnert, and Virupax C. Baligar 
Original Article

\title{
Molecular and morphophysiological responses cocoa leaves with different concentrations of anthocyanin to variations in light levels
}

\author{
Romária Pereira de Araújo ${ }^{\mathrm{a}, *}$, Alex-Alan Furtado de Almeida ${ }^{\mathrm{a}}$, Joedson Pinto Barroso ${ }^{\mathrm{a}}$, \\ Rosilene Aparecida de Oliveira ${ }^{\mathrm{a}}$, Fábio Pinto Gomes ${ }^{\mathrm{a}}$, Dário Ahnert ${ }^{\mathrm{a}}$, Virupax Baligar ${ }^{\mathrm{b}}$

 \\ ${ }^{\mathrm{b}}$ USDA-ARS Beltsville Agricultural Research Center,10300 Baltimore Avenue, Beltsville, MD, USA
}

\section{A R T I C L E I N F O}

\section{Keywords:}

Clonal genotypes

Photosynthesis

Photoinhibition

Flavonoids

Antioxidative metabolism

Gene expression

\begin{abstract}
A B S T R A C T
Theobroma cacao gives higher yield when cultivated in full sun under irrigation system with fertilization, because is a species little conservative in relation the efficiency of water use. On the other hand, T. cacao is usually cultivated under shade conditions in 'Cabruca' and agroforestry systems but with low yield. It has been observed under field conditions that the genotypes of $T$. cacao with high concentration of anthocyanins in young leaves are more tolerant to high irradiance stress when grown in full sun. The accumulation of flavonoids or other UVabsorbing compounds in the leaf epidermis is one of the most important mechanisms to screening out UV-B radiation. The aim of this study was to evaluate the effects of different levels of light on three clonal cacao genotypes ('Catongo', SCA-6 and SJ-2), contrasting in relation to accumulation of anthocyanin levels in young leaves, by evaluations of photosynthesis, activity of guaiacol peroxidase (GPX), chloroplastid pigment contents and vacuolar (anthocyanins) flavonoids contents, anatomical characteristics and gene expression of the leaf. In summary, (i) the anthocyanins contents in leaf level did not provide protection against photoinhibition in $T$. cacao, (ii) the 'Catongo' and SJ-2 genotypes showed greater phenotypic plasticity to the morphology and the chloroplastidic pigment contents in the leaf, while the SCA- 6 genotype allocated more in the flavonoids content and hsp70 gene expression; (iii) the relative expression of the genes $p s b A$ and $p s b O$, did not vary between genotypes under irradiance stress.
\end{abstract}

\section{Introduction}

Cacao, Theobroma cacao L., is one of the world's important agricultural export commodities, with it being cultivated mainly for chocolate production (Almeida and Valle 2007). Traditionally, cacao is cultivated under the shade of a selectively thinned forest. In the Atlantic coastal forests of the states of Bahia and Espirito Santo, Brazil, around $4 \%$ of the world and $75 \%$ of the Brazilian cacao output is obtained using a system locally called 'Cabruca' (Lobão et al., 2007). This system is a special kind of agroforestry in which the understorey is drastically suppressed to introduce cacao, and the density of upper storey trees is reduced. Cacao is also intercropped around the world in planned systems with other species of economic value crops such as Areca catechu, Cocos nucifera (Alvim and Nair 1986; Daswir and Dja'far, 1988; Abbas and Dja'far, 1989), Hevea brasiliensis, Syzigium aromaticum, Cinnamomum zeylanicum, Erythrina fusca (Alvim, 1989a,b), Bactris gasipaes (Almeida et al., 2002) and other Amazonian species (Brito et al., 2002).
However, T. cacao cultivation has also been observed in full sun, in irrigation systems with fertilization. Under full system cacao requires vast amounts of water to achieve high yields (fruit production) in comparison to "Cabruca" and agroforestry cultivation systems (Almeida and Valle, 2007).

Sunlight provides the energy required for plant photosynthetic reactions. In contrast, damage can be caused with excessive exposure to high sun light, while inadequate sun light can limit plant growth and development (Lambers et al., 1998). However, plants have developed sophisticated stress response mechanisms resulting from high light intensities. Low light levels can cause stresses on plants, due to decreased carbon dioxide $\left(\mathrm{CO}_{2}\right)$ assimilation rates, decreased carbohydrate production and decreased growth and development. On the other side, high light levels can damage the photosynthetic machinery (Lambers et al., 1998), known as photoinhibition which may be divided into two types: (i) dynamic photoinhibition, which shows a reduction in quantum efficiency of the photosystem 2 (PS2) reversible, accompanied

\footnotetext{
* Corresponding author.

E-mail addresses: romaria.araujo@si.ifbaiano.edu.br, roaraujo_bio@yahoo.com.br (R.P. de Araújo), alexalan.uesc@gmail.com (A.-A.F. de Almeida), darioa@uesc.br (D. Ahnert), VC.Baligar@ars.usda.gov (V. Baligar).
} 
by a significant increase in the thermal dissipation of excess energy absorbed, indicating that the decrease in the photochemical efficiency should if, in part, to mechanisms photoprotections; and (ii) chronic photoinhibition which occurs when excess absorbed light generates a series of highly reactive oxygen intermediates (ROIs) which can cause serious problems for the photosynthetic machinery (Mittler, 2002) with damage to lipid membrane constituents, pigments and cofactors critical protein subunits, especially the D1 protein, resulting in complete inactivation of the photo-oxidative reaction center (Apel and Hirt, 2004). This damage, if not repaired, lead to a decrease of the photochemical efficiency, which can be characterized by an irreversible decrease the Fv/Fm ratio (quantum efficiency of the PS2) (Hideg and Murata, 1997).

Plants have developed various strategies to cope with adverse conditions, such as plasticity in terms of acclimation to full sunlight and shade, as well as photoprotective mechanisms designed to dissipate excess energy (Demmig-Adams and Adams, 1992). Differences in leaf morphology, anatomy and physiology have been documented for species that are adapted to shaded or full sun environments (Boardman 1977; Björkman 1981; Givnish 1988). Structural foliar changes can also be adaptable, for example, the inactivation of the reaction center of the PS2 (Öquist et al., 1992). Changes in existing leaf physiology and the production of new leaves, that are morphologically and physiologically suitable to the light environment, are acclimation response components (Wyka et al., 2007).

Additionally, plants have developed enzymatic and non-enzymatic protection mechanisms in response to oxidative stress, which are triggered by variations in light intensity. The non-enzymatic mechanism includes metabolites such as anthocyanins and other types of flavonoids (Marchese et al., 2008; Pietrini et al., 2002); while the enzyme mechanism is composed by superoxide dismutase, by catalases and peroxidases, which subsequently act to detoxify $\mathrm{H}_{2} \mathrm{O}_{2}$ (Apel and Hirt 2004). The accumulation of flavonoids or other UV-absorbing compounds in the leaf epidermis is one of the most important mechanisms to screening out UV-B radiation. The accumulation of anthocyanins in leaf level reduces the oxidative stress, induced by exposure to ultraviolet-B (UV-B), and the photoinhibitory damages (Fini et al., 2011). It has been observed under field conditions that the genotypes of $T$. cacao with high content of anthocyanins, in young leaves, are more tolerant to stress promoted by the high light intensity when grown in full sun.

The species $T$. cacao, due to it being a preferentially allogamous species, has a very large variety of genotypes, with striking phenotypic differences. The main objective of this study was to evaluate the effects of different light levels on three clonal genotypes of cocoa ('Catongo', SCA-6 and SJ-2), which were different in terms of the presence of anthocyanins at the foliar level, through photosynthesis evaluations, of guaiacol peroxidase activity (GPX), of the content of chloroplastidic and vacuolar pigments (anthocyanins), of flavonoid content, by anatomical analysis and of gene expression at the foliar level.

\section{Materials and methods}

\subsection{Growth conditions and plant material}

The experiment was performed from September/2010 to November/2011 at the campus of State University of Santa Cruz (UESC), located in the city of Ilhéus, Bahia, Brazil $\left(14^{\circ} 47^{\prime} \mathrm{S}, 39^{\circ} 10^{\prime} \mathrm{W}\right)$. Three clonal genotypes of cocoa were used, which varied in terms of their anthocyanin content in young leaves ('Catongo' - no anthocyanins, SCA-6-low content of anthocyanins and SJ-2-high content of anthocyanins). The genotype 'Catongo' is a natural mutant anthocyanins, with monogenic or qualitative inheritance for this character, selfcompatible and highly productive; with the young leaves (Fig. 1), and seeds devoid of this vacuolar pigment, whose seeds are white; besides being intolerant to witches' broom disease (Bartley, 2005). However, SCA-6 is a wild type genotype, self-incompatible, has small fruits and seeds,; young leaves (Fig. 1), fruits and seeds are slightly red by the presence of vacuolar anthocyanins, as well as having alleles for tolerance to witches' broom (Bartley, 2005). SJ-02 genotype is an autocompatible and highly productivity clonal cultivar that has young leaves (Fig. 1), fruits and seeds intense red coloration due to the high concentration of anthocyanins in vacuolar constituent cells of the tissues and organs. The clonal genotypes were obtained by rooting $16-\mathrm{cm}-$ long stem cuttings from plagiotropic branches at the beginning of secondary growth, containing the apical bud, three auxiliary buds and three leaves. The bottoms of the cuttings $(3 \mathrm{~cm})$ were dipped into chemically inert talcum powder containing indol-3-butyric acid (IBA) at $4 \mathrm{~g} \mathrm{~kg}^{-1}$. Afterwards, each cutting was transferred to a $288-\mathrm{cm}^{3}$ tubelike, black plastic pot containing organic substrate (turf + grinded Pinus sp. barks and grinded coconut fiber at 1:1 ratio) enriched with macro and micronutrients, according to the recommendations for cacao. The planted pots were left at a nursery with $50 \%$ sunlight cover and irrigated by microaspersion. After 4 months of growth these rooted cuttings were transplanted to $12 \mathrm{~L}$ plastic pots, containing soil as substrate, and grown in $100 \%, 50 \%$ and $5 \%$ of full sunlight, during seven months. The different conditions of light levels simulate the main forms of cocoa cultivation in the world $(100 \%$ - monoculture in full sun; $50 \%$ - agroforestry systems with species of economic value such as Areca catechu, Cocos nucifera, Hevea brasiliensis, Syzigium aromaticum, Cinnamomum zeylanicum, with different spacing between plants; and $5 \%$ - an agroforestry system, known as 'Cabruca', is a main cropping system invariably adapted for cultivation of cacao in Brazil, in this system of management, cacao is grown under the shade of native species of the Atlantic Forest. During the experimental period, the photosynthetic photon flux density (PPFD) was monitored in environments with $100 \%$ (full sun), $50 \%$ and $5 \%$ light levels, at the clonal saplings' extremities, with the use of a S-LIA-MOO3 luminous radiation sensor coupled to a micro climatological station: Hobo Micro Station Data Logger (Onset, USA) (Supplementary material 1). Precipitation was monitored using a pluviometer. The mean values ( \pm EP) for air temperature, relative humidity and pluviometric precipitation, obtained during the experimental period, were $24.1 \pm 0.4{ }^{\circ} \mathrm{C}, 87.8 \pm 1.6 \%$ and $457.8 \pm 12.5 \mathrm{~mm}$, respectively.

\subsection{Leaf gas exchange}

During the experimental period, the net photosynthetic rate per unit of leaf area $\left(P_{N}\right)$, stomatal conductance to water vapor $\left(g_{s}\right)$ and leaf transpiration (E) were measured, between 08:00 and 9:00 a.m., on a mature and completely expanded leaf from the end the orthotropic apex axis. Five plants per treatment were assessed using a LI-6400 portable photosynthesis system (Li-Cor, Nebraska, USA) equipped with a 6400-02 B RedBlue artificial light source. For the leaf gas exchange measurements, the artificial light source of the system was adjusted to provide a photosynthetic photon flux density (PPFD) of $700 \mu \mathrm{mol} \mathrm{m} \mathrm{m}^{-2} \mathrm{~s}^{-1}$. To save each reading, the minimum pre-established time for reading stabilization was $60 \mathrm{~s}$ and the maximum $120 \mathrm{~s}$. Also, the reading was saved if the coefficient of variation (CV) for the measurements was less than $0.3 \%$. In addition to PPFD, temperature and atmospheric $\mathrm{CO}_{2}$ within the leaf chamber were maintained constant at $26^{\circ} \mathrm{C}$ and $380 \mu \mathrm{mol}\left(\mathrm{CO}_{2}\right) \mathrm{mol}^{-1}$, respectively.

\subsection{Fluorescence emission}

The Chl fluorescence emission was measured simultaneously on the same leaves $(\mathrm{n}=5)$ used for the gas-exchange measurements, with a leaf chamber fluorometer LI 6400-40, a LED-based fluorescence accessory for the portable photosynthesis system LI-6400 (LI-COR Bioscience Inc., Lincoln, NE, USA).

To assess the Chl fluorescence emission in dark-adapted leaves, the leaf tissue was placed in standard $L I$-COR leaf clips for $30 \mathrm{~min}$ on each leaf prior to each making each measurement. Following dark-adaptation, the leaf tissue was illuminated with a weak-modulated measuring 


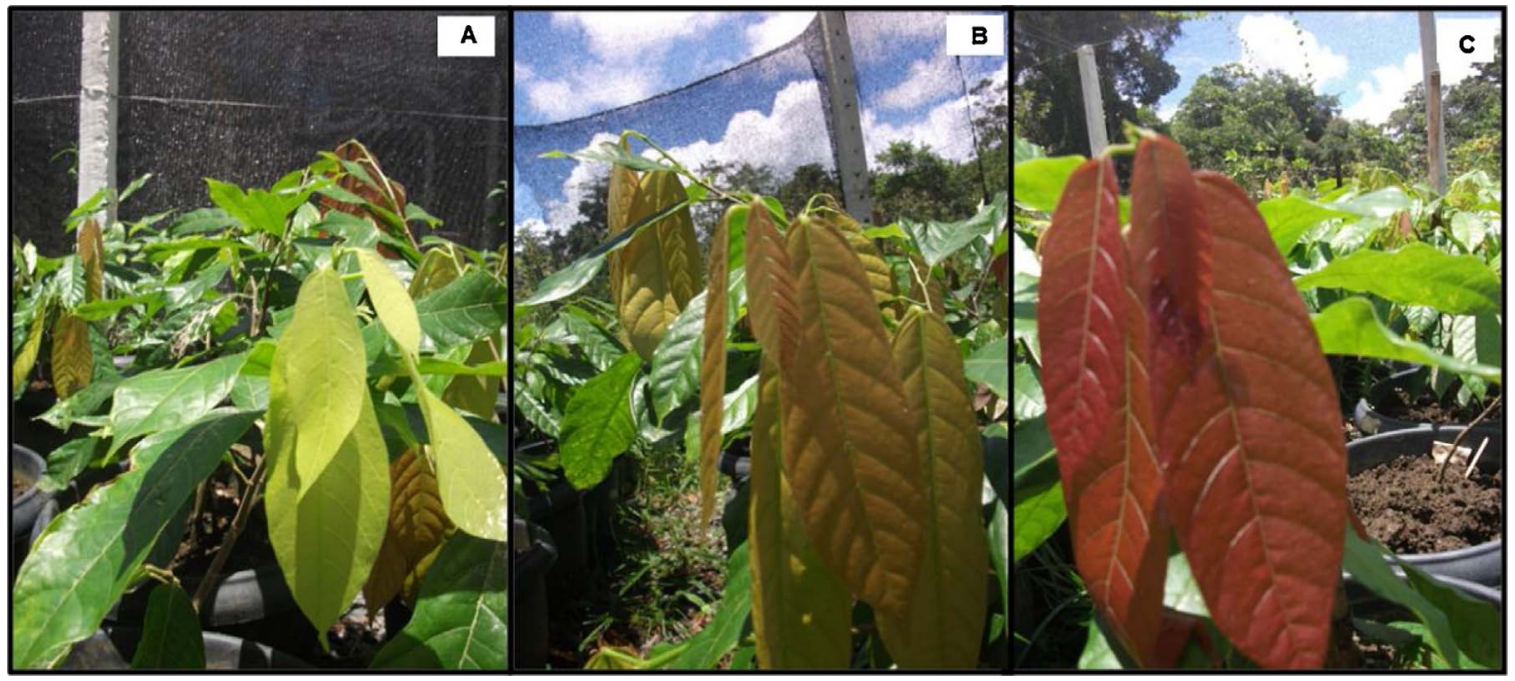

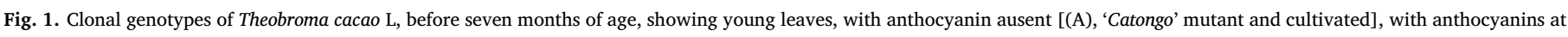
low [(B), SCA-6, wild type little cultivated] and high [(C), SJ-02, cultivated and highly productive] concentrations in vacuolar level.

beam $\left(0.25 \mathrm{kHz},<0.1 \mu \mathrm{mol} \mathrm{m-}{ }^{2} \mathrm{~s}-{ }^{1}, 630 \mathrm{~nm}, 1 \mathrm{~s}\right)$ to obtain the minimal fluorescence $\left(F_{0}\right)$. A saturating white-light pulse $(20 \mathrm{kHz}$; $6000 \mu \mathrm{mol} \mathrm{m-}{ }^{2} \mathrm{~s}^{1}, 630 \mathrm{~nm}, 0.8 \mathrm{~s}$ ) was applied to ensure maximum fluorescence emission (Fm). The maximum quantum yield of photosystem $2\left(F_{v} / F_{m}\right)$ was calculated as $\left.\left[F v / F m=\left(F_{m}-F_{0}\right) / F_{m}\right)\right]$ (Roháček 2002Baker 2008).

\subsection{Anatomical features}

For light microscopy analysis, five mature leaves from five plants of each clonal genotype of $T$. cacao at each light level were collected. Small cuttings $\left(2 \mathrm{~mm}^{2}\right.$ ) of leaves were fixed by $2.5 \%$ glutaraldehyde in $0.1 \mathrm{M}$ cacodylate buffer ( $\mathrm{pH}$ 7.2). The leaf cuttings were dehydrated in graded ethanol series and embedded in historesin (Leica, Heidelberg, Germany). Sections for light microscopy were stained with $1 \%$ toluidine blue and photographed with an Olympus BX5O light microscope (Center Valley, PA, USA). For each species and light level, the thicknesses of the leaf blade, upper and lower epidermis, palisade and spongy parenchyma, and total mesophyll were measured from the light micrographs using the Sigma Scan software (SPSS Inc., San Jose, CA, USA).

\subsection{Photosynthetic pigments}

The content of photosynthetic pigments was determinated in the same leaves used for the gas-exchange measurements $(n=5)$, using methodology described by Hiscox and Israelstam (1979), with some modifications. After incubation of three leaf discs $\left(0.5 \mathrm{~cm}^{2}\right)$ with $4 \mathrm{~mL}$ of dimethylsulfoxide (DMSO) saturated with $\mathrm{CaCO}_{3}$ at $65^{\circ} \mathrm{C}$ for $24 \mathrm{~h}$, absorbance of the extracts was determined in a microplate spectrophotometer (VersaMax, Molecular Devices, CA, USA) at wavelengths of 480, 649, and $665 \mathrm{~nm}$. Chl $a$, Chl $b$, total Chl, and carotenoid (car) content were determined using equations described by Wellburn (1994) for DMSO extracts. The contents were expressed in a fresh weight basis.

\subsection{Total flavonoids and anthocyanins}

The content of total flavonoids and anthocyanins was determined in mature leaves lyophilized, from five clonal plants in each treatment, following the methodological procedures as described by Lees and Francis (1972). In addition, these procedures also determined the same compounds in young leaves from three clonal genotypes, but only in environments with $50 \%$ light levels. $0.5 \mathrm{~g}$ from each sample was macerated in $30 \mathrm{~mL}$ of extracting solution, containing $95 \%$ ethanol and $1.5 \mathrm{~mol} \mathrm{HCl} \mathrm{L}{ }^{-1}$, in the proportion of 85: 15, where they remained for
$12 \mathrm{~h}$ at $4{ }^{\circ} \mathrm{C}$. The volume was subsequently filled to $100 \mathrm{~mL}$ with the extracting solution. Absorbance readings were taken using a microplate spectrometer (VERSAmax), at wavelengths corresponding to $535 \mathrm{~nm}$ and $370 \mathrm{~nm}$, in order to determine the content of total anthocyanins and flavonoids, respectively. The absorbance readings were converted in accordance with Lees and Francis (1972).

\subsection{Activity of Guaiacol peroxidase}

To analyze the activity of guaiacol peroxidase (GPX; EC1.11.1.7) samples were collected from the second and third mature leaves of three cacao genotypes grown in different light environments, and then lyophilized. Enzyme activity was determined using the methodology described by Pirovani et al. (2008) and expressed with the increased consumption of guaicol in $\mu \mathrm{mol} \mathrm{g} \mathrm{g}^{-1}$ (DW) $\mathrm{min}^{-1}$. The conversion of data from absorbance values, at $470 \mathrm{~nm} \mathrm{~g}^{-1}$ (DW) $\mathrm{min}^{-1}$ to guaiacol consumption in $\mu \mathrm{mol} \mathrm{g}^{-1}$ (DW) $\mathrm{min}^{-1}$, was done using the equation: $\mathrm{y}=0.0189+0.1284 \mathrm{x} \quad\left(R^{2}=0.99\right) \quad$ obtained from a standard guaiacol- GPX curve.

\subsection{Quantitative real time PCR analysis}

The second mature leaf from the stem apex was harvested. The samples were stored at $-80{ }^{\circ} \mathrm{C}$ after being frozen in liquid nitrogen, and then lyophilized. RNA was extracted from leaves at different treatments with RNAqueous (Ambion ${ }^{\circ}$ ) kit. Afterwards, the RNA purity and integrity was tested by electrophoresis in $1 \%$ agarose gel. The RNA samples were used for cDNA synthesis using Revertaid H-Minus Reverse Transcriptase (Fermentas), according to the instructions of the manufacturer using oligo $\mathrm{d}(\mathrm{T}) 18$ primers. The reactions were incubated at $65{ }^{\circ} \mathrm{C}$ for $5 \mathrm{~min}, 37^{\circ} \mathrm{C}$ for $5 \mathrm{~min}, 42^{\circ} \mathrm{C}$ for $60 \mathrm{~min}$ and $70{ }^{\circ} \mathrm{C}$ for $10 \mathrm{~min}$. The qPCR was performed in a 'Real Time PCR' (Applied Biosystems, modelo 7500) using detection sequence (fluorophore) non-specific SYBR Green I (Fermentas). The abundance of transcripts was analyzed using specific primers (Table 1). To test the quality of these primers, the specificity and identity of the reverse transcription products, the qPCR products were monitored after each PCR, using curve analysis of reaction products capable of distinguishing gene-specific from non genespecific products. The reaction mix consisted of: cDNA template (500 ng), $0.5 \mu \mathrm{M}$ of each primer, and $10 \mu \mathrm{L}$ fluorophore SYBR Green I in a final reaction volume of $20 \mu \mathrm{L}$. The temperature of PCR products was raised from 55 to $99^{\circ} \mathrm{C}$ at a rate of $1{ }^{\circ} \mathrm{C} / 5 \mathrm{~s}$, and the resulting data were analyzed using the LightCycler software. Only a single band with a characteristic melting point was observed for each sample, indicating 
Table 1

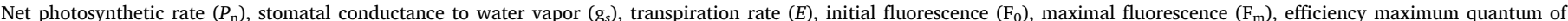

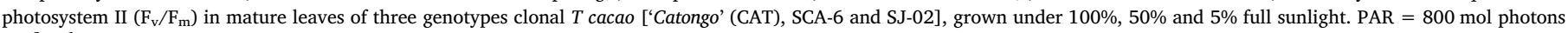
$\mathrm{m}^{-2} \mathrm{~s}^{-1}$. Mean values of four replicates $( \pm \mathrm{SE}$ ). Lowercase letters indicate comparisons between treatments and capital between genotypes, by Tukey test $(\mathrm{P}<0.05)$.

\begin{tabular}{|c|c|c|c|c|c|c|c|}
\hline \multirow[t]{2}{*}{ Genótipo } & \multirow[t]{2}{*}{ Full sunlight } & \multirow{2}{*}{$\frac{P_{n}}{\mu \mathrm{mol}\left(\mathrm{CO}_{2}\right) \mathrm{m}^{-2} \mathrm{~s}^{-1}}$} & \multirow{2}{*}{$\begin{array}{l}g_{s} \\
\mathrm{~mol}\left(\mathrm{H}_{2} \mathrm{O}\right) \mathrm{m}^{-2} \mathrm{~s}^{-1}\end{array}$} & $E$ & \multirow[t]{2}{*}{$\mathrm{F}_{0}$} & \multirow[t]{2}{*}{$\mathrm{F}_{\mathrm{m}}$} & \multirow[t]{2}{*}{$\mathrm{F}_{\mathrm{v}} / \mathrm{F}_{\mathrm{m}}$} \\
\hline & & & & $\mathrm{mmol}\left(\mathrm{H}_{2} \mathrm{O}\right) \mathrm{m}^{-2} \mathrm{~s}^{-1}$ & & & \\
\hline \multirow[t]{3}{*}{ 'Catongo' } & $100 \%$ & $10.39 \pm 0.47 \mathrm{Aa}$ & $0.16 \pm 0.01 \mathrm{Aa}$ & $1.58 \pm 0.09 \mathrm{Aa}$ & $215.30 \pm 4.18 \mathrm{Aa}$ & $638.92 \pm 36.60 \mathrm{Cc}$ & $0.65 \pm 0.02 \mathrm{Cc}$ \\
\hline & $50 \%$ & $8.40 \pm 0,29 \mathrm{Ab}$ & $0.09 \pm 0.00 \mathrm{Ac}$ & $0.97 \pm 0.04 \mathrm{Ab}$ & $214.30 \pm 6.68 \mathrm{Aa}$ & $932.22 \pm 43.58 \mathrm{Bb}$ & $0.77 \pm 0.01 \mathrm{Bb}$ \\
\hline & $5 \%$ & $7.89 \pm 0,37 \mathrm{Ab}$ & $0.12 \pm 0.02 \mathrm{Ab}$ & $0.96 \pm 0.08 \mathrm{Ab}$ & $214.15 \pm 4.43 \mathrm{Aa}$ & $1154.37 \pm 29.51 \mathrm{Ba}$ & $0.81 \pm 0.00 \mathrm{Ba}$ \\
\hline \multirow[t]{3}{*}{ SCA-6 } & $100 \%$ & $2.81 \pm 0.28 \mathrm{Cc}$ & $0.04 \pm 0.01 \mathrm{Ca}$ & $0.48 \pm 0.13 \mathrm{Cb}$ & $227.27 \pm 18.28 \mathrm{Aa}$ & $809.87 \pm 50.05 \mathrm{Ab}$ & $0.71 \pm 0.04 \mathrm{Ab}$ \\
\hline & $50 \%$ & $6.76 \pm 0.58 \mathrm{Ba}$ & $0.05 \pm 0.00 \mathrm{Ba}$ & $0.64 \pm 0.04 \mathrm{Ba}$ & $218.82 \pm 19.09 \mathrm{Aa}$ & $887.85 \pm 39.12 \mathrm{Cb}$ & $0.75 \pm 0.04 \mathrm{Ab}$ \\
\hline & $5 \%$ & $4.79 \pm 0.22 \mathrm{Bb}$ & $0.05 \pm 0.01 \mathrm{Ba}$ & $0.44 \pm 0.06 \mathrm{Cb}$ & $217.90 \pm 24.04 \mathrm{ABa}$ & $1207.82 \pm 15.19 \mathrm{Aa}$ & $0.82 \pm 0.02 \mathrm{Ba}$ \\
\hline \multirow[t]{3}{*}{ SJ-02 } & $100 \%$ & $7.59 \pm 0.35 \mathrm{Ba}$ & $0.11 \pm 0.01 \mathrm{Ba}$ & $1.33 \pm 0.09 \mathrm{Ba}$ & $222.40 \pm 4.63 \mathrm{Aa}$ & $694.73 \pm 79.60 \mathrm{Bc}$ & $0.67 \pm 0.03 \mathrm{Ab}$ \\
\hline & $50 \%$ & $7.68 \pm 0.38 \mathrm{Aa}$ & $0.07 \pm 0.01 \mathrm{Ab}$ & $0.88 \pm 0.08 \mathrm{Ab}$ & $249.26 \pm 35.97 \mathrm{Aa}$ & $1029.40 \pm 173.24 \mathrm{Ab}$ & $0.73 \pm 0.08 \mathrm{Ab}$ \\
\hline & $5 \%$ & $7.39 \pm 0.52 \mathrm{Aa}$ & $0.06 \pm 0.00 \mathrm{Bb}$ & $0.66 \pm 0.05 \mathrm{Bb}$ & $199.57 \pm 1.85 \mathrm{Ba}$ & $1172.95 \pm 13.00 \mathrm{Ba}$ & $0.83 \pm 0.00 \mathrm{Aa}$ \\
\hline
\end{tabular}

that the $\mathrm{qPCR}$ had produced a specific product for primer used. To confirm that the qPCR had produced only genes of interest, the PCR products were separated and visualized in agarose gel at $1 \%$. Threshold cycle $\left(\mathrm{C}_{\mathrm{T}}\right)$ values were determined using the LightCycler software. Numbers regarding the relative expression of genes were calculated as a percentage of the control treatments (50\% full sunlight), using the 2 $-\Delta \Delta \mathrm{Ct}$ method (Livak and Schmittgen 2001) and $\beta$ - Tubulina as endogenous control in order to detect changes in transcript number (Supplementary material 2). All reactions were prepared in triplicate and performed twice.

\subsection{Statistics}

The experiment was conducted in a completely randomized design, using a $3 \times 3$ factorial arrangement which corresponded to three contrasting light environments (100\%, 50\% e 5\% full sunlight) and three T. cacao genotypes, with five replicates, and one plant per experimental unit. The results were submitted to a variance analysis (ANOVA), followed by Tukey's mean comparison test ( $\mathrm{p}<0.05)$. All statistical procedures were performed using the Statistica 6.0 software (Statsoft Inc., College Station, TX, USA).

\section{Results}

\subsection{Leaf gas exchange}

During the procedures to evaluate the leaf gas exchange, it was verified that, in $100 \%$ light, the genotype 'Catongo' presented greater $\mathrm{CO}_{2}$ assimilation (73\% and $27 \%$ ), stomatal conductance $(75 \%$ and $31 \%$ ) and transpiration (69\% and 16\%) than the SCA- 6 and SJ-2 genotypes, respectively. Referring to the other two light environments (50\% and 5\%), the genotypes 'Catongo' and SJ-2 did not exhibit significant differences $(\mathrm{p}<0.05)$ in terms of $\mathrm{CO}_{2}$ assimilation, while SCA- 6 reduced its $\mathrm{CO}_{2}$ assimilation by $20 \%$, and $40 \%$ in light environments of $50 \%$ and $5 \%$, respectively (Table 1 ).

In the current study, intragenotypic responses were not observed at the different light levels. The genotype 'Catongo' showed the highest value of $\mathrm{CO}_{2}$ assimilation in $100 \%$ light, but there was no significant difference $(\mathrm{p}<0.05$ ) observed between genotypes in the $50 \%$ and $5 \%$ light levels. However, for the genotype SCA-6, the value of $\mathrm{CO}_{2}$ assimilation was higher in 50\% light and reduced at 5\% (29\%) and 100\% (58\%) light levels. On the other hand, the $\mathrm{CO}_{2}$ assimilation values for the SJ-2 genotype did not significantly differ $(\mathrm{p}<0.05)$ between the light levels (Table 1). Genotype SCA-6 with low content of anthocyanin seems to adapt to partial shade.

\subsection{Fluorescence emission}

While assessing chlorophyll fluorescence emissions at the foliar level, it was noted that there was no significant difference ( $p<0.05)$ for the $F_{v} / F_{m}$ ratio, in SCA-6 and SJ-2 in $100 \%$ light, when compared with $50 \%$ light environment. It was also verified that the $F_{v} / F_{m}$ values were lower in full sun compared to the $5 \%$ light environment. Generally considering, it was possible to observe that $F_{O}$ did not present significant inter- and intragenotypic differences $(\mathrm{p}<0.05)$; whereas $F_{m}$ showed the same trend as the $F_{v} / F_{m}$ ratio for the genotypes "Catongo" and SCA-6 (Table 1).

\subsection{Foliar anatomy}

The genotype 'Catongo' showed no significant differences ( $\mathrm{p}<0.05$ ) for leaf lamina thickness (LLT), total mesophyll thickness (TMT), palisade parenchyma thickness (PPT) or spongy parenchyma thickness (SPT) in 100\% and 50\% light levels. In contrast, in 5\% light, the 'Catongo' genotype give reductions of $24.5 \%, 23 \%, 21 \%$ and $20 \%$ in thickness values for LLT, TMT, PPT and SPT, respectively. On the other hand, the SCA-6 genotype has not shown any significant differences ( $\mathrm{p}<0.05$ ) of thickness values for LLT, TMT, PPT and SPT in all the three light levels. It was also observed, for the SJ-2 genotype, that the thickness values for LLT, TMT, PPT and SPT were higher in the 50\% light level, whereas in $100 \%$ and $5 \%$ light levels there was a reduction in the LLT and TMT thickness values (Figs. 2 and 3).

\subsection{Photosynthetic pigments}

The content of Chl $a$ and Chl T, for genotypes 'Catongo' (2.0 and $\left.2.89 \mathrm{mg} \mathrm{g}^{-1} \mathrm{FW}\right)$ and SJ-02 (2.4 and $\left.3.5 \mathrm{mg} \mathrm{g}^{-1} \mathrm{FW}\right)$, were similar in the $5 \%$ light levels, whereas at same light level SCA- 6 give a reduction of approximately $40 \%$ in concentration of these pigments compared to the SJ-2. On the other hand, for SJ-2 in 5\% light, the content of Chl b was higher compared to 'Catongo' and SCA-6. In contrast, the values of Chl b content in 'Catongo' and SCA- 6 in 100\% light were no different from those in 50\% light levels, whereas for SJ-2 there were significant differences ( $\mathrm{p}<0.05$ ) observed in content of Chl $a$, Chl T and Car content in full sun light (Fig. 4).

For the genotypes 'Catongo' and SCA- 6 , the $C h l a / b$ ratio was similar in the three light levels, while for SJ-2 there was a greater $C h l a / b$ ratio in $50 \%$ light. The Car/ChlT ratio values did reduce along with decreased light intensity. However, for the genotypes SCA-6 and SJ-2, the Car/ChlT ratio differed significantly $(\mathrm{p}<0.05)$ in the three light levels, whereas the ratio remained constant for 'Catongo' in $100 \%$ and 50\% light levels (Fig. 4).

\subsection{Total flavonoids and anthocyanins}

The content of flavonoids found in the leaves, in $100 \%$ and $5 \%$ light, ranged from $26.4-33.71$ and $9.36-11.38 \mathrm{mg} \mathrm{g}^{-1}$ quercetin, respectively (Fig. 5). SCA-6 genotype in $100 \%$ light showed the greatest content of 

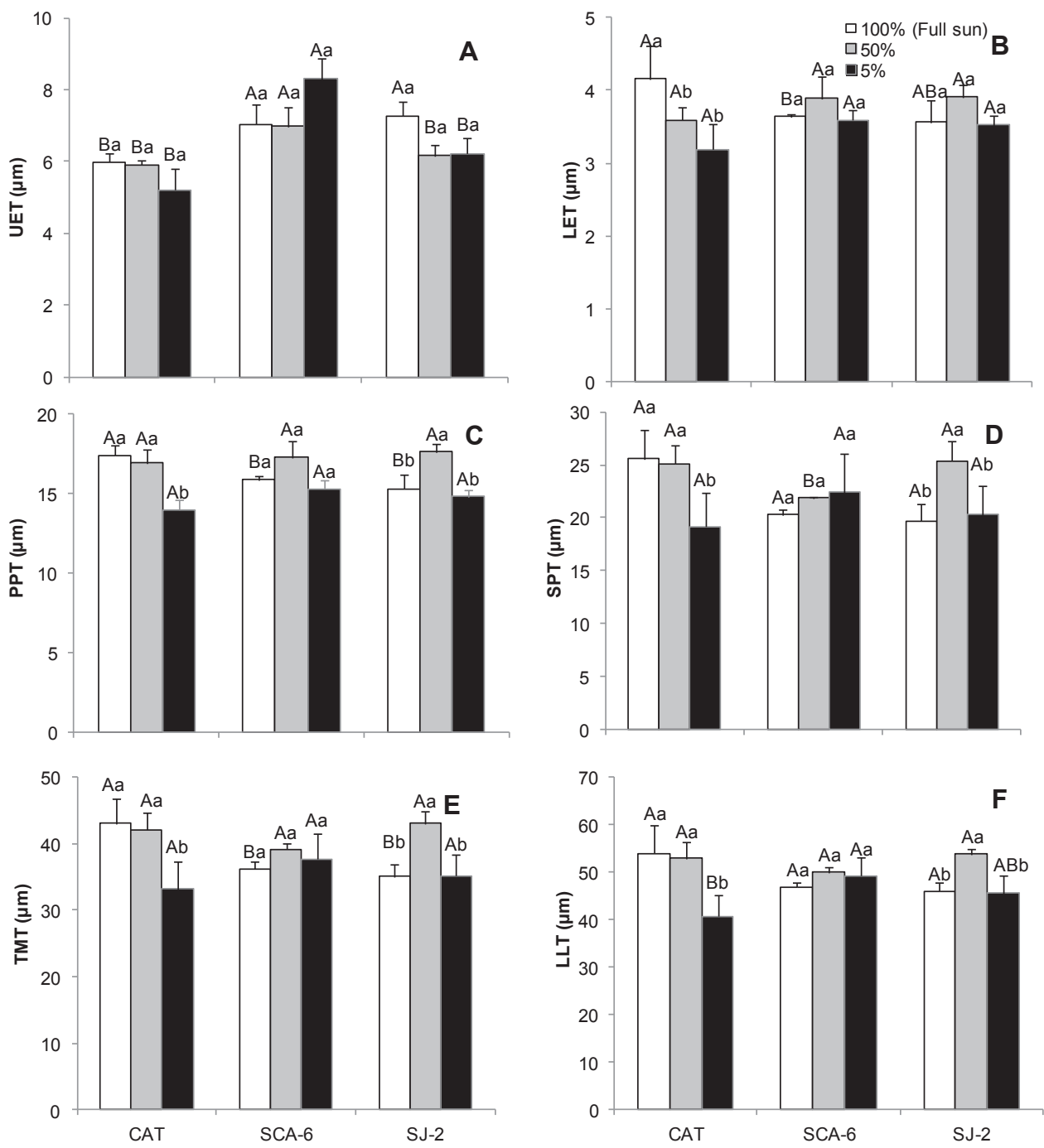

Fig. 2. Thickness of the Upper Epidermis (UET, A), of the Lower Epidermis (LET, B), of the Palisade Parenchymas (PPT, C), of the Spongy Parenchymas (SPT, D), of the Mesophyll (TMT, E), of the Leaf Lamina (LLT, F) in mature leaves, three clonal genotypes of T. cacao ['Catongo' (CAT), SCA- 6 and SJ02 ], grown under $100 \%, 50 \%$ and $5 \%$ full sunlight. Mean values of four replicates $( \pm$ SE). Lowercase letters indicate comparisons between treatments and capital between genotypes, by Tukey test $(\mathrm{P}<0.05)$.
CAT

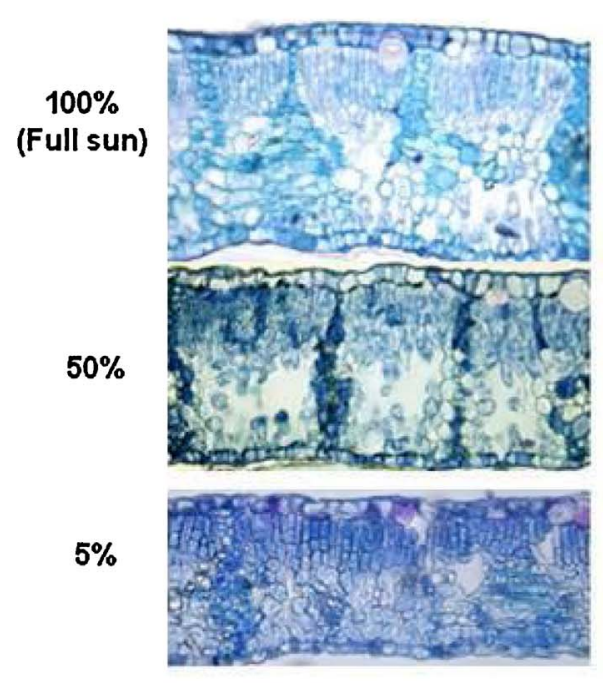

SCA-6
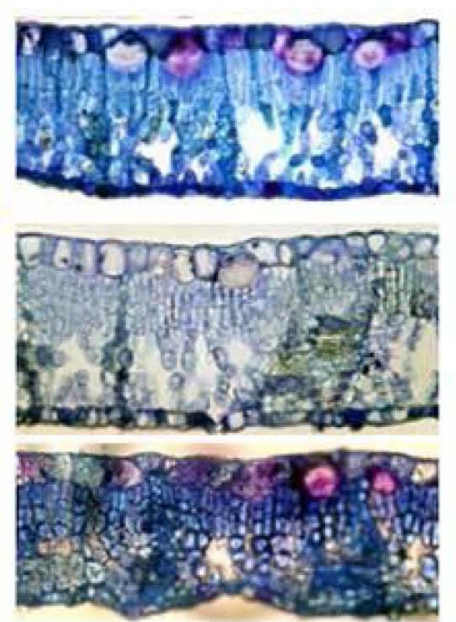

SJ-02

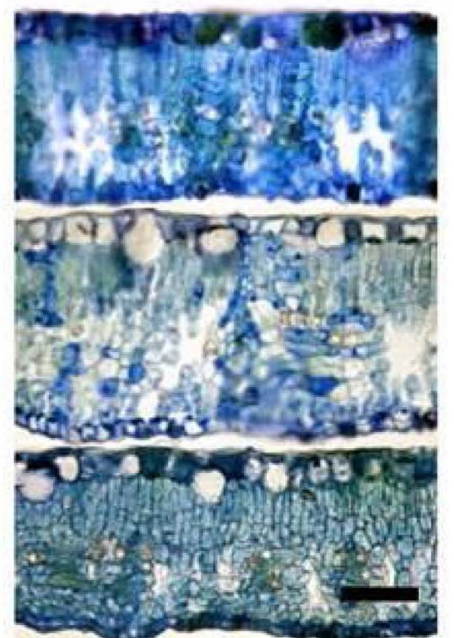

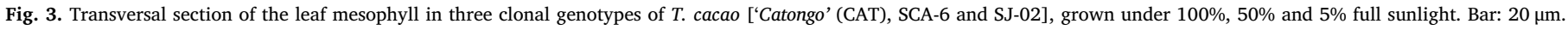



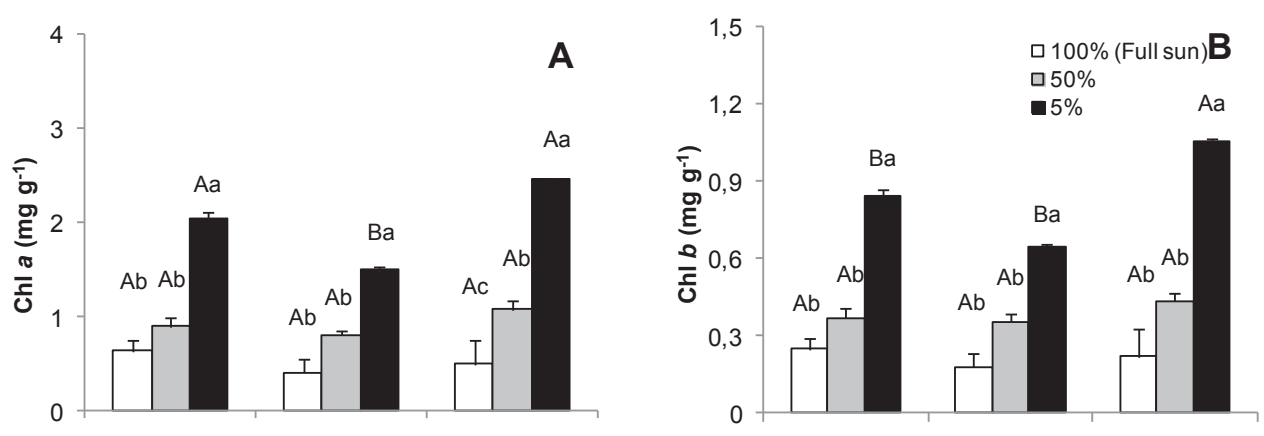

Fig. 4. Levels of chlorophyll $a$ (Chl $a$ ) (A), chlorophyll $b(\mathrm{Chl} b)$ (B), total chlorophyll $(a+b)(\mathrm{Chl} \mathrm{T})$ (C) and carotenoids (Car) (D), ratio of chlorophyll $a$ / $b(\mathrm{Chl} a / b)(\mathrm{E})$ and ratio total chlorophyll/carotenoids (ChlT/Car) (F), expressed in fresh biomass in mature leaves, three clonal genotypes of $T$. cacao ['Catongo' (CAT), SCA-6 and SJ-02], grown under $100 \%, 50 \%$ and $5 \%$ full sunlight. Mean values of five replicates $( \pm \mathrm{SE}$ ). Lowercase letters indicate comparisons between treatments and capital between genotypes, by Tukey test $(\mathrm{P}<0.05)$.
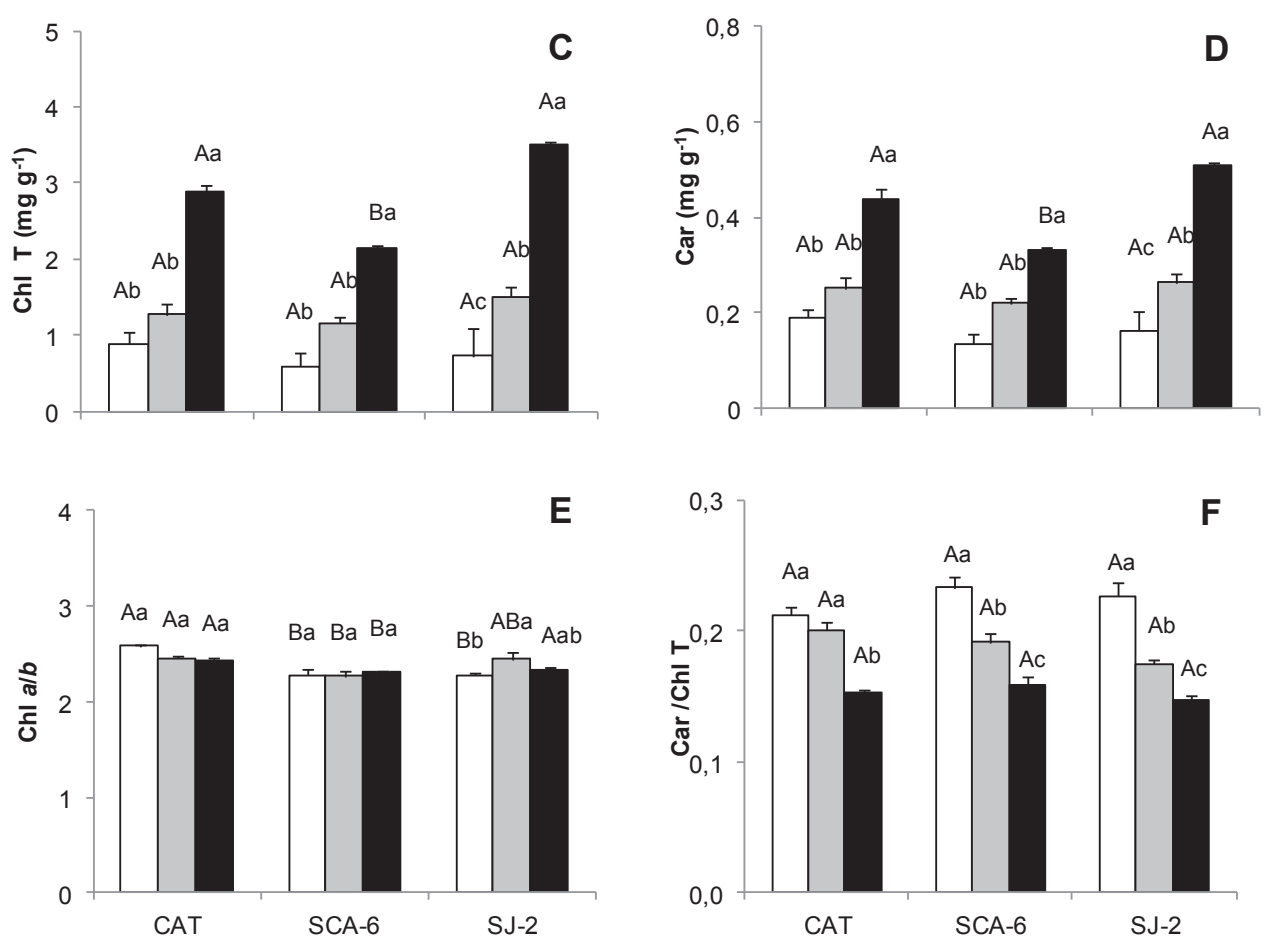

foliar flavonoids; whereas for the genotypes 'Catongo' and SJ-2, the flavonoid content did not significantly differ $(\mathrm{p}<0.05)$. The same pattern that was observed in $100 \%$ light was also observed in the $50 \%$ light level for all three genotypes of $T$. cacao. On the other hand, there was no significant inter-genotypic difference $(p<0.05)$ observed for flavonoids contents in the $5 \%$ light level (Fig. 5A).

For all evaluated genotypes, it was observed that the mature leaves give a low content of anthocyanins, which differs from the flavonoid content, whose values were much greater. In different light levels, the anthocyanins content varied from $0.8-1.59 \mathrm{mg} \mathrm{g}^{-1}$, with the smallest content being observed in 'Catongo' in 100\% light, and the largest anthocyanin contents were observed in SJ-2 genotype in $5 \%$ light (Fig. 5B). On the other hand, in a 50\% light level, 'Catongo' give a $0.4 \mathrm{mg} \mathrm{g}^{-1}$ anthocyanins content in young leaves, while SJ-2, in the same light level, give anthocyanin content of $22.6 \mathrm{mg} \mathrm{g}^{-1}$. In addition, young leaves from the clonal genotypes SCA- 6 and SJ-2 showed greater contents of anthocyanins ( 85 and $95 \%$, respectively) than those from mature leaves in $50 \%$ light. The same result was not observed for 'Catongo' (Supplementary material 3). It was also verified, in the different light intensities and during the two foliar development stages (young and mature leaves), that the SCA- 6 genotype give highest contents of flavonoids. However, it was possible to see that the lowest contents of flavonoids were found in young leaves, whose values were 19, 20 and 22\% lower for the genotypes 'Catongo', SCA- 6 and SJ-2, respectively, when compared with the mature leaves (Supplementary material 3).

\subsection{Guaiacol peroxidase activity (GPX)}

GPX activity was observed to be greater at light levels of $5 \%$ for all clonal genotypes evaluated, whose increments were $26.5 \%, 39 \%$ and $52 \%$ for genotypes SJ-2, 'Catongo' and SCA-6, respectively, when compared with the $50 \%$ light environment. On the other hand, when the GPX activity in $100 \%$ light was compared with activity in $50 \%$ light, the genotypes did not show the same trend. The genotype 'Catongo' give a $25 \%$ increase in GPX activity in $100 \%$ light, when compared to the $50 \%$ light level. On the other hand, SCA- 6 did not significantly differ $(\mathrm{p}<0.05)$ in $100 \%$ light, whereas SJ-2 give lower GPX activity (33\%) (Fig. 6).

\subsection{Gene expression}

The expression of the genes $p s b A$ and $p s b O$ at the leaf level are associated with biosynthesis of the proteins PsbA PsbO, respectively. These are components of photosystem 2 (PS2) that belongs to the photochemical phase of the photosynthesis, which gives similar trends for both clonal genotypes of $T$. cacao, albeit in different proportions. There were greater expressions of $p s b A$ and $p s b O$ for 'Catongo' in $100 \%$ and $5 \%$ light levels when compared to $50 \%$ of light, where their expression increased by 200 and 100 times and 8 and 5 times, 

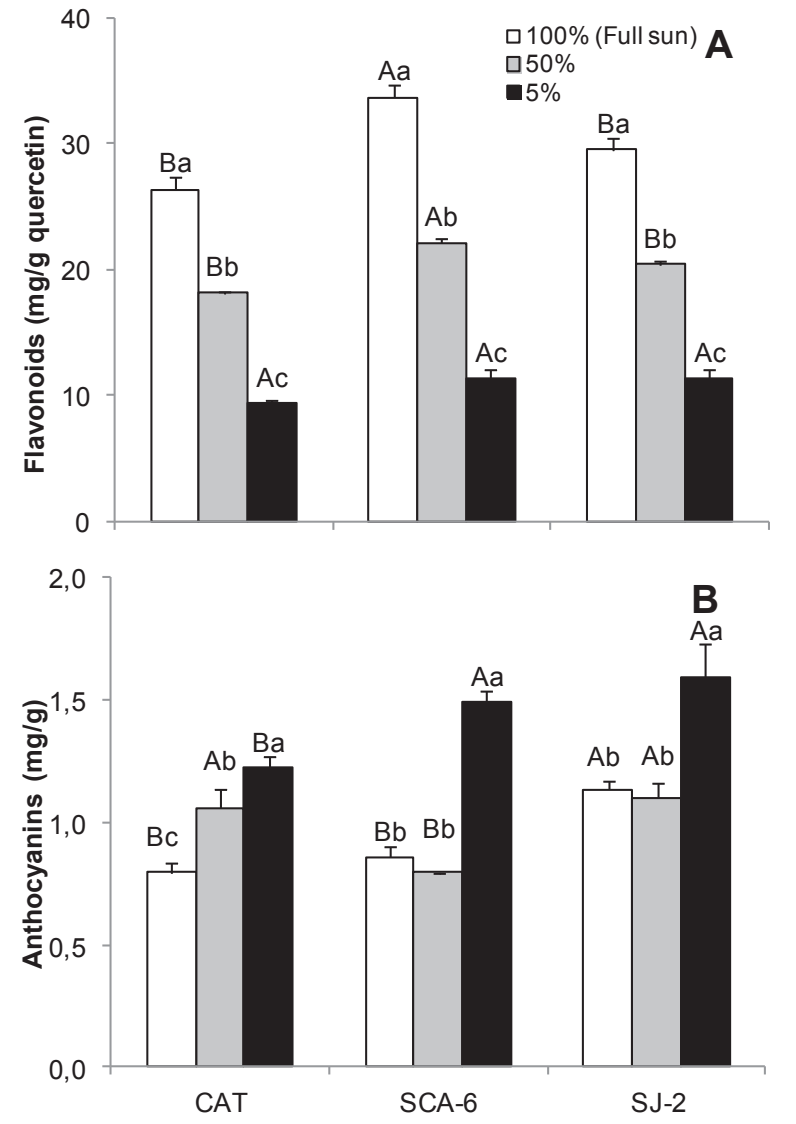

Fig. 5. Levels of flavonoides (A) and anthocyanins (B) leaves mature three clonal genotypes of T. cacao ['Catongo' (CAT), SCA- 6 and SJ-02], grown under $100 \%, 50 \%$ and $5 \%$ full sunlight. Mean values of three replicates ( \pm SE). Lowercase letters indicate comparisons between treatments and capital between genotypes, by Tukey test $(\mathrm{P}<0.05)$.



Fig. 6. Activity of guaiacol peroxidase (GPX) in mature leaves, three clonal genotypes of T. cacao ['Catongo' (CAT), SCA- 6 and SJ-02], grown under $100 \%, 50 \%$ and $5 \%$ full sunlight. Mean values of five replicates $( \pm \mathrm{SE}$ ). Lowercase letters indicate comparison between treatments and capital between genotypes at Tukey test $(\mathrm{P}<0.05)$.

respectively. On the other hand, for SJ-2, there were only small increases in the expressions of $p s b A$ and $p s b O$ in $100 \%$ and $5 \%$ light levels, which corresponded to increases by 2 and 2.5 times and 3 and 5 times, respectively, compared to the control; whereas for SCA- 6 there was a repression of $p s b A$ in $5 \%$ light levels, and an increase by 2 times in 100\% light levels (Figs. 7 and 8).

Regarding the gene $h s p 70$, for the genotypes 'Catongo' and SJ-2, there was an observed repression of this gene at the leaf level in $100 \%$

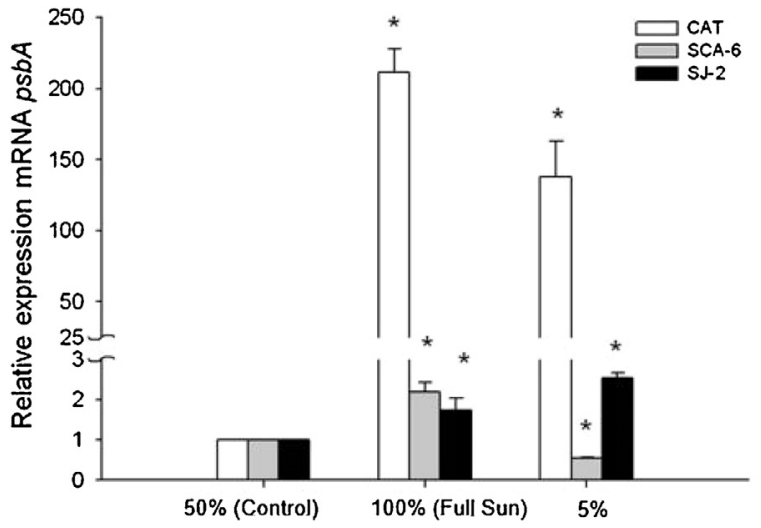

Fig. 7. Relative expression of the $p s b A$ gene in mature leaves of three genotypes clonal $T$. cacao ['Catongo' (CAT), SCA- 6 and SJ-02], grown under 100\%, 50\% and 5\% full sunlight. Mean values of five replicates $( \pm \mathrm{SE})$.

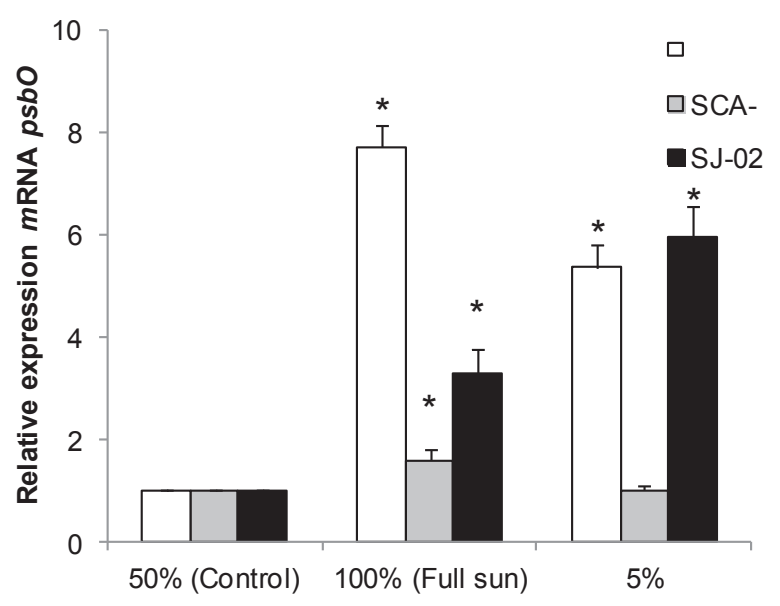

Fig. 8. Relative expression of the $p s b O$ gene in mature leaves, three clonal genotypes of $T$. cacao ['Catongo' (CAT), SCA-6 and SJ-02], grown under 100\%, 50\% and 5\% full sunlight. Mean values of five replicates $( \pm S E)$.

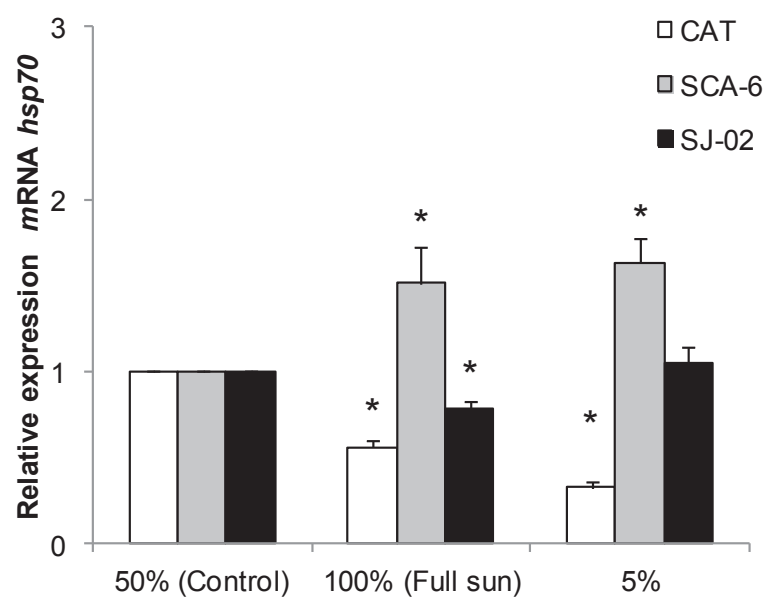

Fig. 9. Relative expression of the $h s p 70$ gene in mature leaves, three clonal genotypes of T. cacao ['Catongo' (CAT), SCA- 6 and SJ-02], grown under $100 \%, 50 \%$ and $5 \%$ full sunlight. Mean values of five replicates $( \pm \mathrm{SE})$.

light, when compared to 50\% light; whereas for the SCA- 6 genotype, a slight increase in its expression was observed. On the other hand, in 5\% light 'Catongo' reduced the expression of this gene, while SJ-2 showed no significant difference $(\mathrm{p}<0.05$ ) when compared to the control. However, for SCA- 6 there was an increment in its expression in this light environment (Fig. 9). 


\section{Discussion}

\subsection{Phenotypic plasticity and photosynthesis}

Leaf phenotypic plasticity responses observed by the clonal genotype 'Catongo' are consistent with those observed with other plant species (Boardman, 1977; Bjorkman, 1981; Lambers et al., 1998), this may be due to the fact that leaves in the sun were thicker than those in the shade. On the other hand, the genotype SCA- 6 gives lesser phenotypic plasticity when compared to the other two genotypes of T. cacao. Leaf thickness from the genotype 'Catongo' was greater than other two genotypes, which also increased their leaf thickness when subjected to high light intensity. This increase was mainly induced by the greater thickening of the palisade parenchyma (PPT) and the spongy parenchyma (SPT), due to the greater cell elongation, since the number of layers in these tissues remained constant.

Increased foliar thickness translates into high energy costs for plants and reflects an elevated net photosynthetic rate displayed by the genotype 'Catongo'; this was due to $\mathrm{CO}_{2}$ availability, which becomes greater in the lacunar of the mesophyll, and the lacunar of the chloroplasts that are close to the cell's surface, thereby facilitating carboxylation by Rubisco, since $\mathrm{CO}_{2}$ diffusion in liquid medium is lower (Oguchi et al., 2005; Terashima et al., 2006). In addition, the increase in leaf thickness, observed for the genotype 'Catongo', also has a role of decreasing photooxidative effects, thereby increasing the area for energy dissipation (Wyka et al., 2007).

According to Samuel Björkman (1981), genotypes of T. cacao were expected to form a higher Chl b content compared to the Chl a content, in low light intensity conditions, in order to increase lower energy wavelength absorption. However, this was not confirmed in the current study due to the proportional increase in Chl $a$ and $C h l b$ content. In this way, for all the evaluated genotypes of $T$. cacao, there was no observed decreasing tendency in the $C h l a / b$ ratio along with reduced light intensity. This fact is justified by the increase in the Chl a content, which was not accompanied by an increase in Chl b content, in the same light intensity. One of the factors that can interfere with the significant increase of Chl b content, in addition to light intensity, is the quality of the light that hits the leaf surface. Eskins et al., 1989 reported that blue light is essential for sun-type chloroplasts, whereas red light is the same for shade or sun-type chloroplasts. However, it is likely, even in conditions of low light intensities, that there were no changes in light quality during this experiment as black plastic screens were used to attenuate global radiation.

An increase of the Car/ChlT ratio was observed for the three evaluated genotypes of $T$. cacao, along with increasing light intensity. In high light intensity environments plants utilize xanthophylls cycles (carotenoids) for non-photochemical quenching (Demming-Adams and Adams 1992). Despite the carotenoid content having increased in shaded environments, the proportion was not equal to the increase in the Chl T content, thereby justifying the greater Car/ChlT ratio in full sun (Demming-Adams and Adams 1992). On the other hand, based on the potential quantum yield of PS2 $\left(F_{v} / F_{m}\right)$, it is possible to see the existence of photoinhibition for the three genotypes of $T$. cacao grown in full sun, as evidenced by the decrease in the $F_{v} / F_{m}$ values. However, in this case the photoinhibition may have been dynamic, due to activation of the photoprotection mechanisms, thereby allowing heat dissipation without affecting protein from the photosynthetic apparatus (Baker 2008).

\subsection{Antioxidative metabolism}

In plants, foliar chloroplasts, when exposed to excessive light, are the principle cellular organelles that are, along with the mitochondria, responsible for producing ROS, (Gil and Tuteja, 2010). The plants eliminate ROS through enzymatic and non-enzymatic mechanisms. However, when the antioxidative metabolism is unable to eliminate all the ROS, there is oxidative stress. For the evaluated genotypes of $T$. cacao, the foliar flavonoid content, which belongs to the non-enzymatic pathway, were higher in greater light intensity. Similar results were found by Tattini et al. (2005) in Phillyrea latifolia, which presented foliar flavonoid content levels that were not significant in low light intensities but were significant in full sun. Furthermore, Fini et al. (2011) demonstrated that excessive light, regardless of the proportion of wavelengths, regulates flavonoid biosynthesis.

In vitro and in vivo experiments have demonstrated the role of flavonoids as quenchers and, or ROS inhibitors (Agati et al., 2010). This role becomes more evident in light of the variety of existing classes in the flavonoid family, both hydrophilic and hydrophobic, which means that they can be found in various cellular compartments (Hernández et al., 2008). When present in chloroplasts, flavonoids act as excellent superoxide removers that are generated by the photosynthetic machinery (Agati et al., 2010). However, other forms, such as cytosolic ones, also have important roles to play, because ROS cross the membranes of cellular organelles where they were generated, the example being $\mathrm{H}_{2} \mathrm{O}_{2}$, passing towards the cytosol, using the aquaporin channels (Mittler et al., 2011).

Additionally, flavonoids are beneficial to plants under excessive light as they absorb short wavelengths, such as UV rays, that are extremely harmful to biomolecules (Harborne and Williams 2000). Furthermore, they are involved with increasing the number of trichomes and specialized epithelial cells, which mitigate the effects caused by light (Goh et al., 2012); they also act, along with the enzymatic system, to remove ROS, such as substrates for GPX and polyphenol oxidase (Agati and Tatiini, 2010). In this way, the SCA-6 genotype, which is regarded as wild, is better protected against oxidative stress than ' $\mathrm{Ca}$ tongo' and SJ-2, despite these two genotypes having presented increases in the content of this metabolite in full sun.

Low concentrations of anthocyanins in mature leaves were observed in the three clonal genotypes of T. cacao, when compared to their young leaves. This is due to the fact that, in many plant species, this vacuolar pigment is found at high levels in young leaves, with it having a tendancy to disappear as the leaf matures (Ranjan et al., 2014; Hatier and Gould 2009). It was also noted that the young leaves from 'Catongo' had low levels of anthocyanins, a genotype that is regarded as a mutant for this characteristic; whereas the levels found in young leaves from SCA-6 and SJ-2 were higher than those found in mature leaves.

Young leaves are more sensitive to excessive light energy, due to the immaturity of their photosynthetic apparatus, where the presence of anthocyanins minimizes the effects of light (Steyn et al., 2002). Additionally, anthocyanins are products of a biochemical route that involves the synthesis of several important metabolites to counter herbivory; whose red color may be an evolutionary adaptation, thereby indicating the presence of phenolic compounds, the purpose of which is to repel insects (Gould et al., 2008). According to Karageorgou and Manetas (2006), young green leaves from Quercus coccifera are attacked more often by insects than its young red leaves. Thus, different from those of 'Catongo', leaves from the SCA- 6 genotype and, mainly, from SJ-2 protect themselves from excessive light during their young phase.

Typically, oxidative stress is greater under excessive light, because of the greater activation of the electron transport chain in the chloroplasts and mitochondria (Gil and Tuteja, 2010). In contrast, GPX activity (EC 1.11.1.7), in the evaluated genotypes of T. cacao, was higher in the environment with $5 \%$ light. However, there are reports that oxidative stress enzymes decrease their activities during periods of severe stress caused by excessive light, as was seen for the ascorbate peroxidases (APX) and for the superoxide dismutase (SOD) in species Ligustrum vulgare (Fini et al., 2011). On the other hand, the genotype 'Catongo' showed higher GPX activity in full sun, when compared to the other two evaluated genotypes. 


\subsection{Molecular responses}

Significant inter-genotypic differences $(\mathrm{p}<0.05)$ were verified compared to the relative expression of the gene $p s b A$. There was an overexpression of the gene psbA for genotype 'Catongo' in 100\% light. The regulation the gene's expression through light occurs mostly at translational and post-transcriptional levels, so that the chloroplasts maintain a stable pool of m-RNA for $p s b A$ (Dwivedi and Bhardwaj, 1995). However, Kettunen et al. (1997), while working with Pisum sativum, demonstrated that light regulated the expression of the $p s b A$ gene at both the transcriptional and translational level.

The genotypes 'Catongo' and SCA- 6 presented a higher expression of the gene $p s b O$ in $100 \%$ light, which has an extrinsic protein of PS2 as a product, this is considerably important for oxygen evolution during the photochemical phase of photosynthesis (Popelkova and Yocum, 2011). In addition, the protein PsbO, along with PsbP e PsbQ, plays an important role in the accumulation of PS2 reaction centers, which may be involved as an assembling/stabilizing factor of this photosystem (Bricker and Frankel, 2011). The protein PsbO can perform this function through its ability to phosphorylate the D1 protein, thereby increasing its stability under stress conditions, the example being excessive light. This justifies the increase of its expression at high light intensities (Bricker and Frankel, 2011).

The expression of the gene $h s p 70$, whose product is a chloroplastic protein associated with heat shock, was repressed in the genotypes 'Catongo' and SJ-2, no matter what the light levels were. On the other hand, there was an overexpression (upregulation) of this gene in the genotype SCA-6. Heat shock proteins are also known as stress proteins, they are activated in diverse restricting situations (Al-Whaibi, 2011). The HSP70 protein functions to (i) prevent protein aggregation; (ii) remodel those which lose their configuration under stress conditions (Scarpeci et al., 2008); (iii) and regulate the gene expression of other HSFS, including the small HSP, which, when located in the chloroplast, reduce photooxidative damage (Akerfelt et al., 2010). Thus, the genotype SCA-6, despite not having presented a great deal of foliar phenotypic plasticity, showed important foliar responses against stress caused by light, including the production of antioxidants, as per the elevated content of flavonoids; and with the increase in the expression of $h s p 70$, since $\mathrm{H}_{2} \mathrm{O}_{2}$ also enables its expression (Scarpeci et al., 2008).

In conclusion, this study showed that the differences presented by the three evaluated clonal genotypes of $T$. cacao, in regards to variations in light intensity, are not associated with the presence or absence of foliar anthocyanins, because the content of this pigment was greater during the young foliar phase. The clonal genotypes 'Catongo' and SJ-2, when subjected to different light levels, presented a higher phenotypic plasticity for its anatomy and for chloroplastic pigment content at the foliar level; while the SCA- 6 genotype invested more in the flavonoid content and in the gene expression of chloroplast heat shock protein hsp70, belonging to the HSP70 family. At high light intensity, the genotypes SCA-6 and SJ-2 give a more efficient non-enzymatic antioxidant protection system, through increasing flavonoid content and GPX activity. In contrast, the genotype 'Catongo' more efficiently used its enzymatic and non-enzymatic protection systems, in comparison to the other two genotypes. The expression of genes PsbA and PsbO did not allow the evaluated genotypes of $T$. cacao to differ in relation to the variations in light intensity.

\section{Acknowledgments}

The second author gratefully acknowledges the Conselho Nacional de Desenvolvimento Científico e Tecnológico (CNPq), Brazil, for the concession of a fellowship of scientific productivity. Araújo was supported by FAPESB (Fundação de Amparo a Pesquisa do Estado da Bahia). This study was funded by a grant from USDA, within an international cooperative agreement with UESC.

\section{Appendix A. Supplementary data}

Supplementary data associated with this article can be found, in the online version, at http://dx.doi.org/10.1016/j.scienta.2017.06.008.

\section{References}

Öquist, G., Chow, W.S., Anderson, J.M., 1992. Photoinhibition of photosynthesis represents a mechanism for the long-term regulation of FSII. Planta 186, 450-463.

Abbas, B.S., Dja'far, D., 1989. Sensitivity analysis of cacao cultivation: relative profitability of coconut and Leucaena glauca L. (L. leucocephala) as shade plantsbased on a case study at Bah Lias Plantation, North Sumatra. Bull Perkebunnan 20, 97-103.

Agati, G., Tatiini, M., 2010. Multiple functional roles of flavonoids in photoprotection. New Phytol. 186, 786-793.

Akerfelt, M., Morimoto, R.I., Sistonen, L., 2010. Heat shock factors: integrators of cell stress, development and lifespan. Nature 11, 545-555.

Al-Whaibi, M.H., 2011. Plant heat-shock proteins: a mini review. J. King Saud University 23, 139-150.

Almeida, A.-A.F., Valle, R.R., 2007. Ecophysiology of the cacao tree. Braz. J. Plant Physiol. 19, 425-448.

Almeida, C.M.V.C., Müller, M.W., Sena-Gomes, A.R., Matos, P.G.G., 2002. Sistemas agroflorestais com o cacaueiro como alternativa sustentável para uso em áreas desmatadas, no estado de Rondônia, Brasil. Agrotropica 14, 109-120.

Alvim, R., Nair, P.K.R., 1986. Combination of cacao with other plantation crops: an agroforestry system in Southeast Bahia. Brazil Agrofor. Syst. 4, 3-15.

Alvim, P.T., 1989a. Tecnologias apropriadas para a agricultura nos trópicos úmidos. Agrotrópica 1, 5-26.

Alvim, R., 1989b. O cacaueiro (Theobroma cacao L.) em sistemas agrossilviculturais. Agrotrópica 1, 89-103.

Apel, K., Hirt, H., 2004. Reactive oxygen species: metabolism, oxidative stress, and signal transduction. Annu. Rev. Plan Biol. 55, 373-399.

Baker, N.R., 2008. Chlorophyll fluorescence: a probe of photosynthesis In vivo. Annu. Rev. Plant Biol. 59, 89-113.

Bartley, Basil G.D., 2005. The genetic diversity of cacao and its utilization. Cabi.

Björkman, O., 1981. Responses to different quantum flux densities. In: In: Lange, O.L. Nobel, P.S., Osmond, C.B., Ziegler, H. (Eds.), Encyclopedia of Plant Physiology Vol. I. Springer-Verlag, pp. 57107 (New Series).

Boardman, N.K., 1977. Comparative photosynthesis of sun and shade plants. Annu. Rev. Plant Physiol. 28, 355-377.

Bricker, T.M., Frankel, L.K., 2011. Auxiliary functions of the PsbO, FSbP and PsbQ proteins of higher plant Photosystem II: A critical analysis. J. Photochem. Photobiol. 104, 165-178.

Brito, A.M., Silva, G.C.V., Almeida, C.M.V.C., Matos, P.G.G., 2002. Sistemas agroflorestais com o cacaueiro: uma tentativa de busca do desenvolvimento sustentável do estado do Amazonas. Brasil Agrotrópica 14, 61-72.

Daswir, H.A.S., Dja'far, D., 1988. Analysis of cacao shaded with coconut (Cocos nucifera) compared with Leucaena glauca in North Sumatra. Bull Perkebunan 19, 99-106.

Demmig-Adams, B., Adams III, W.W., 1992. Photoprotection and other responses of plants to high light stress. Annu. Rev. Plant Physiol. Plant Mol. Biol. 43, 599-626.

Dwivedi, U., Bhardwaj, R., 1995. D1 protein of photosystem II: The light sensor in chloroplasts. J. Biosci. 1, 35-47.

Eskins, K., Westhoff, P., Beremand, P.D., 1989. Light quality and irradiance level interaction in the control of expression of light-harvesting complex of photosystem 11 . Plant Physiol. 91, 163-169.

Fini, A., Brunetti, C., Di Ferdinando, M., Ferrini, F., Tattini, M., 2011. Stress-induced flavonoid biosynthesis and the antioxidant machinery of plants. Plant Signal. Behav. 6, 709-711.

Gil, S.S., Tuteja, N., 2010. Reactive oxygen species and antioxidant machinery in abiotic stress tolerance in crop plant. Plant Physiol. Biochem. 48, 909-930.

Givnish, T.J., 1988. Adaptation to sun and shade: a whole-plant perspective. Aust. J. Plant Physiol. 15, 63-92.

Goh, G.-H., Ko, S.-K., Koh, S., Kim, Y.-J., Bae, H.-J., 2012. Photosynthesis and environments: photoinhibition and repair mechanisms in plants. J.. Plant Biol. 55, 93-101.

Gould, K.S., Davies, K., Winefield, C., 2008. 2008. Anthocyanins: Biosynthesis, Functions and Applications. Springer.

Harborne, J.B., Williams, C.A., 2000. Advances in flavonoid research since 1992. Phytochemistry 55, 481-504.

Hatier, J.H.B., Gould, K.S., 2009. Anthocyanin function in vegetative organs. In: Gould, K., Davies, K.M., Winefield, C. (Eds.), Anthocyanins. Springer-Verlag, Heidelberg, pp. $1-19$.

Hernández, I., Alegre, L., Breusegem, F.V., Munné-Bosch, S., 2008. How relevant are flavonoids as antioxidants in plants? Trends Plant Sci. 3, 125-132.

Hideg, E., Murata, N., 1997. The irreversible photoinhibition of the photosystem II complex in leaves of Vicia faba under strong light. Plant Sci. 130, 151-158.

Hiscox, J.D., Israelstam, G.F., 1979. Different methods of chlorophyll extraction. Can. J. Bot. $57,1332$.

Karageorgou, P., Manetas, Y., 2006. The importance of being red when young: anthocyanins and the protection of young leaves of Quercus coccifera from insect herbivory and excess light. Tree Physiol. 26, 613-621.

Kettunen, R., Pursiheimo, S., Rintamaki, E., Van Wijk, K.-J., Aro, E.-M., 1997. Transcriptional and translational adjustments of PsbA gene expression in mature chloroplasts during photoinhibition and subsequent repair of photosystem II. Eur. J. Biochem. 247, 441-448.

Lambers, H., Chapin III, F.S., Pons, T.L., 1998. Plant Physiological Ecology. Springer 
Verlag N.Y., New York, USA.

Lees, D.H., Francis, F.J., 1972. Standardization of pigment analyses in cranberries. HortScience 7, 83-84.

Livak, K.J., Schmittgen, T.D., 2001. Analysis of relative gene expression data using realtime quantitative PCR and the $2^{-\Delta \Delta \mathrm{Ct}}$ method. Methods 25, 402-408.

Lobão, D.E., Setenta, W.C., Lobão, E.S.P., Curvelo, K., Valle, R.R., 2007. Cacau cabruca: sistema agrossilvicultural tropical. In: Ciência, Tecnologia E Manejo Do Cacaueiro. R.R. Valle. Gráfica e Editora Vital Ltda, Ilhéus, pp. 290-323.

Marchese, J.A., Mattana, R.S., Ming, L.C., Broetto, F., Vendramini, P.F., Moraes, R.M., 2008. Irradiance stress responses of gas exchange and antioxidant enzyme contents in pariparoba [Pothomorphe umbellata (L.) Miq.] plants. Photosynthetica 46, 501-505.

Mittler, R., Vanderauwera, S., Suzuki, N., Miller, G., Tognetti, V.B., Vandepoele, K., Gollery, M., Shulaev, V., Van Breusegem, F., 2011. ROS signaling: the new wave? Trends Plant Sci. 6, 300-309.

Mittler, R., 2002. Oxidative stress, antioxidants and stress tolerance. Trends Plant Sci. 7 (9), 405-410.

Oguchi, R., Hikosaka, K., Hirose, T., 2005. Leaf anatomy as a constraint forphotosynthetic acclimation: differential responses in leaf anatomy toincreasing growth irradiance among three deciduous trees. Plant Cell Environ. 2, 916-927.

Pietrini, F., Iannelli, M.A., Massacci, A., 2002. Anthocyanin accumulation in the illuminated surface of maize leaves enhances protection from photo inhibitory risks at low temperature, without further limitation to photosynthesis. Plant Cell Environ. 25, 1251-1259.

Pirovani, C.P., Carvalho, H.A.G., Machado, R.C.R., Gomes, D.S., Alvim, F.C., Pomella, A.W.V., Gramacho, K.V., Cascardo, J.C.M., Pereira, G.A.G., Micheli, F., 2008. Protein extraction for proteome analysis from cacao leaves and meristems, organs infected by
Moniliophthora perniciosa the causal agent of the witches'broom disease. Electrophoresis 29, 2391-2401.

Popelkova, H., Yocum, C.F., 2011. PsbO, the manganese-stabilizing protein: analysis of the structure-function relations that provide insights into its role in photosystem II. J. Photochem. Photobiol. 104, 179-190.

Ranjan, S., Singh, R., Singh, M., Pathre, U.V., Shirke, P.A., 2014. Characterizing photoinhibition and photosynthesis in juvenile-red versus mature-green leaves of Jatropha curcas L. Plant Physiol. Biochem. 79, 48-59.

Roháček, K., 2002. Chlorophyll fluorescence parameters: the definitions, photosynthetic meaning, and mutual relationships. Photosynthetica 40 (01), 13-29.

Scarpeci, T.E., Zanor, M.I., Valle, E.M., 2008. Investigating the role of plant heat shock proteins during oxidative stress. Plant Signal. Behav. 10, 856-857.

Steyn, W.J., Wand, S.J.E., Holcroft, D.M., Jacobs, G., 2002. Anthocyanins in vegetative tissues: a proposed unified function in photoprotection. New Phytol. 155, 349-361.

Tattini, M., Guidi, L., Morassi-Bonzi, L., Pinelli, P., Remorini, D., Degl'innocenti, E., Giordano, C., Massai, R., Agati, G., 2005. On the role of flavonoids in the integrated mechanisms of response ofLigustrum vulgare and Phillyrea latifolia to high solar radiation. New Phytol. 2, 457-470.

Terashima, I., Hanba, Y.T., Tazoe, Y., Vyas, P., Yano, S., 2006. Irradiance and phenotype: comparative eco-development of sun and shade leaves in relation to photosynthetic CO2 diffusion. J. Exp. Bot. 57, 343-354.

Wellburn, A.R., 1994. The spectral determination of chlorophylls a and b, as well as total carotenoids, using various solvents with spectrophotometers of different resolution. J. Plant Physiol. 144, 307-314.

Wyka, T., Robakowsky, P., Ytkowiak, R., 2007. Acclimation of leaves to contrasting irradiance in juvenile trees differing in shade tolerance. Tree Physiol. 27, 1293-1306. 


\section{Supplementary material}

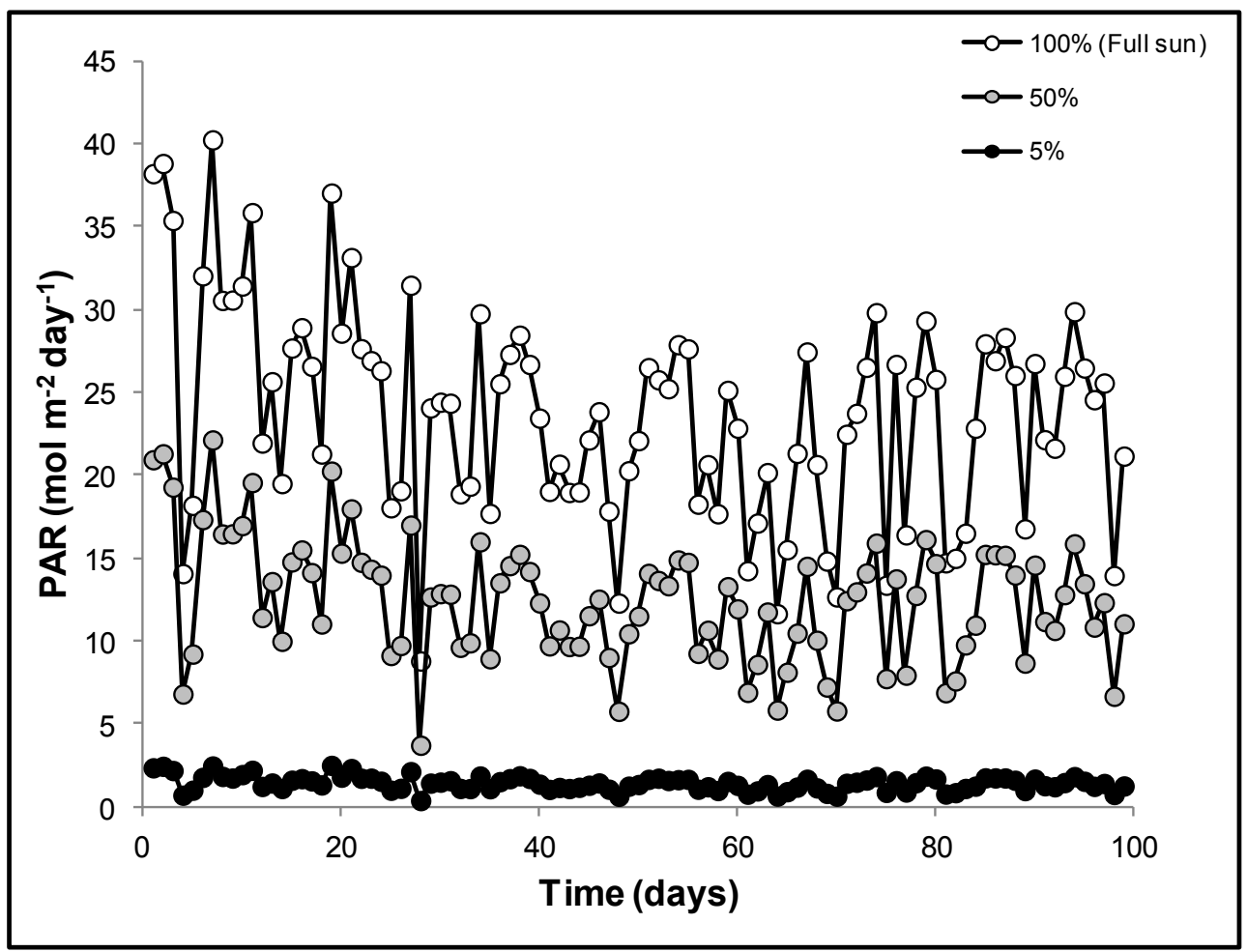


Supplementary material 1 :

Figure: Photosynthetically active radiation (PAR) monitored in three light environments during the trial period.

Supplementary material 2

Table: Primer pairs specific gene that were used in the analysis of qRT-PCR

\begin{tabular}{ll}
\hline Gen & Primer \\
\hline PsbA & Forward: 5'-GGTTTGCACTTTTACCCGA-3' \\
& Reverse: 5'-CTCATAAGGACCGCCATT-3' \\
\hline PsbO & Forward: 5'-GCAAACGCTGAAGGAGTT-3' \\
& Reverse: 5'-GGCTTGAAGGCAAATGAGTC-3' \\
\hline hsp70 & Forward: 5' CGATGGCTGCCCTCAATC 3' \\
& Reverse: 5' GATGAATCTGAAGGCCCACTTT 3' \\
\hline$\beta$-Tubulina & Forward: 5'-TGCAACCATGAGTGGTGTTCA- 3' \\
& Reverse: 5'-CAGACGAGGGAAGGGAATGA- 3'
\end{tabular}



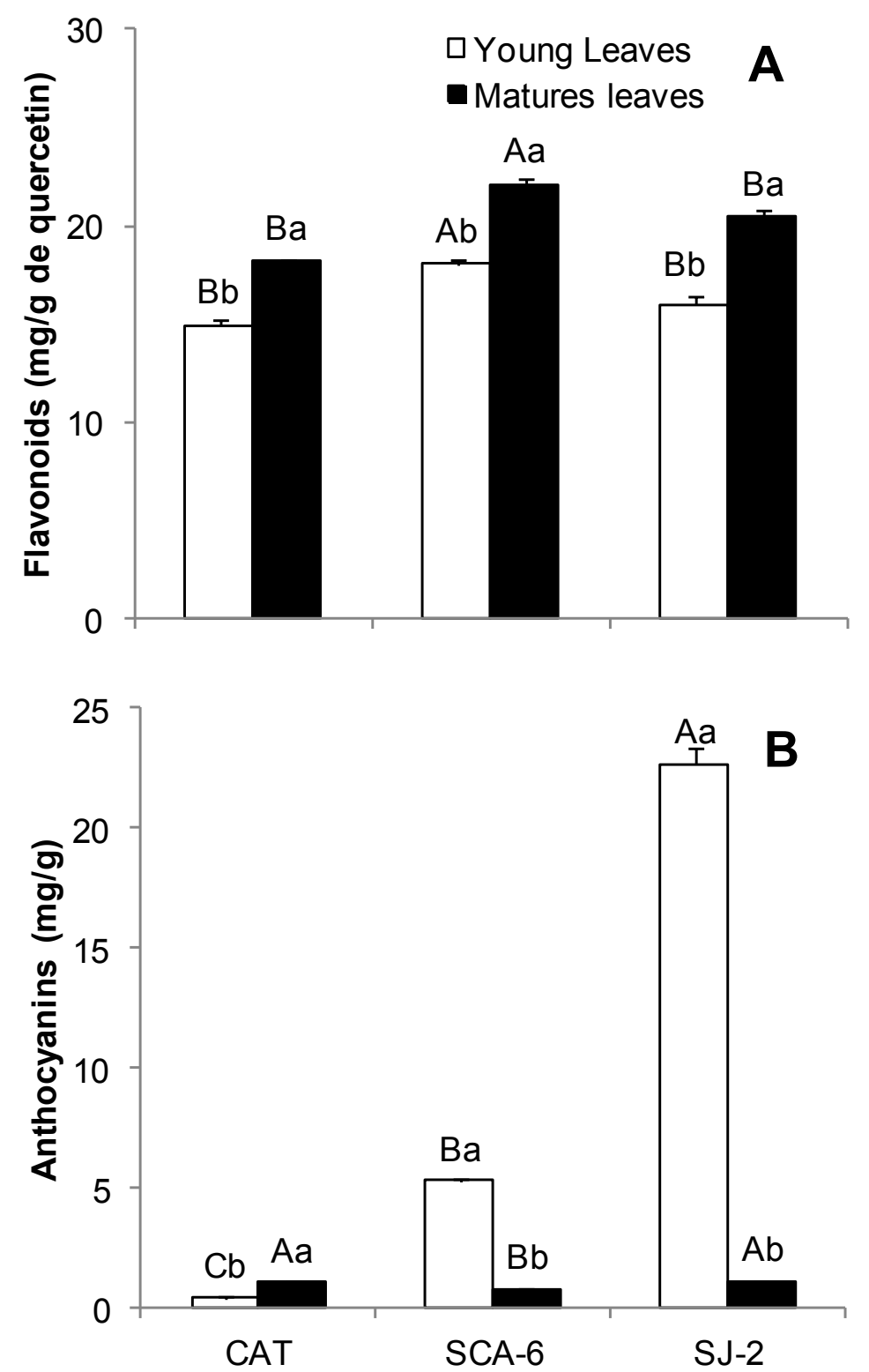

Supplementary material 3

Figure: Levels of flavonoids (A) and anthocyanins (B) young and mature leaves, three clonal genotypes of T. cacao ['Catongo' (CAT), SCA-6 and SJ-02], grown 
at $50 \%$ full sunlight. Mean values of three replicates ( \pm SE). Lowercase letters indicate comparison between treatments and capital between genotypes at Tukey test $(\mathrm{P}<0.05)$. 